\title{
LINGUISTIC MEANING AS A PART OF THE CONCEPTUAL MODEL OF THE WORLD*
}

\begin{abstract}
The paper deals with the concept of the model of the word. It concerns a pre-linguistic stage of language acquisition, descriptive content of proper names and interpretation by means of a conceptual system. The model of the world comprises all aspects of being conscious. It is a system, a unity, a background of our conscious life; perception, language, notions, concepts, are its aspects. The more we know about cognitive processes, functions and structure of the mind, the better we understand the nature of language; the more we know about language, the better we understand the nature of the mind. Linguistic meaning as it was shown by the studies of language and categories acquisition, has its origin in the aforementioned model. That is why linguistic meanings are not ready-made contents, ideas, semantic entities, etc. but rather systems of procedures that constitute sense of speech acts. The approach to linguistic meaning as a part of an individual conceptual system, a system of information that mirrors cognitive, linguistic and non-verbal experience of an individual, is much of help in understanding efficacy of language, forming of beliefs, convictions, and also introducing new meanings.
\end{abstract}

Keywords: model of the world; language; mind

1. Introduction. 2. The pre-language stage of language learning. 3. The descriptive content of proper names and occasional expressions. 4. Sense as interpretation by means of a conceptual system. 5. Examples of the role of context in interpretation of semantic anomalies 6. Conclusions.

\section{INTRODUCTION}

The term "model of the world" was introduced by an outstanding psychiatrist and French philosopher Henri Ey in his work La conscience. "A model of the world" encompasses a number of aspects that make up the phenomenon of being conscious and constitutes a systemic,

* This article was originally published in Polish as: M. Maciejczak, Znaczenia jako fragment pojęciowego modelu świata, Studia Philosophiae Christianae 44(2009)1, 39-55. The translation of the article into English was financed by the Ministry of Science and Higher Education of the Republic of Poland as part of the activities promoting science - Decision No. 676/P-DUN/2019 of 2 April 2019. Translation made by GROY Translations. 
hierarchical unity ${ }^{1}$ Language is one of such aspects. Language participates in perception and cognition as an objectifying medium in which the results of cognition are formulated and an individual model of the world is created: "No object, given to us in the traditional sense of the word, could be presented without this model in the course of our conscious life, and we must constantly refer to it to recognise the objects we are dealing with; otherwise we would not be able to distinguish any elements or moments of our area of consciousness, and this area would remain completely empty"2. In the hierarchical structure of the model of the world, sensory experiences serve as the basis for orientation of the subject in the world and the formation of concepts and meanings assigned by humans to the objects of experience, including the "true or false" qualification ${ }^{3}$. The unity labelled "the model of the world" should be referred to in order to understand how experience and knowledge are created, the presentation of what we directly experience and the semantic (conceptual) representation of experience. Moreover, it also explains how a specific autonomy of conscious being and its personal character is created in the course of personal experience and, especially constitutive for the issue of meaning, in the social context of communication. The concept of a model of the world can help to overcome a certain one-sidedness of naturalistic and computational theories of the mind, shed light on the issues of the relationship between perception and language, the meaning of linguistic expressions, the conceptual scheme, mental representation, intentionality and rationality. It is both an opportunity and an actual need.

The study of cognitive processes, functions and structure of the mind enables better understanding of language. On the other hand, the more we know about language, the better we understand the nature of the mind. The importance of language, as the studies of language acquisition in children and the genesis of language cate-

1 H. Ey, La conscience, Paris 1956, 1968².

2 A. Półtawski, Problematyka doświadczenia „zewnętrznego” w filozofii Romana Ingardena, Część II, Kwartalnik Filozoficzny 24(1996)4, 110.

3 M. Maciejczak, Brentano i Husserl. Pytanie epistemologiczne, Warszawa 2001. 
gories have shown, refers to a broader, dynamic model of the mind, to which the system of concepts belongs as its element. In its light, the linguistic meaning is not a ready-made content, ideas, semantic components, etc., but a system of procedures, operations to determine the sense of an utterance. Having such a system leads to the development of a targeted reference of the human being to the world, the participants of communication and oneself, as criteria of the subjective importance of cognition. The assertion that the meaning given to signs (content) is determined by the content of the conceptual system in which the interpretation is made, on the one hand, questions the Cartesian image of the mind as a place of "ready" meanings, ideas that are the basis for the creation of our knowledge of the world, and on the other hand, the notion of meaning as an independent individual, semantic existence, and objective thought. To indicate the broader context of the process of language acquisition and its meanings - to include linguistic meaning as part of an individual conceptual system, a system of information that reflects the individual's cognitive, verbal and non-verbal experience, will help to better understand the effectiveness of language, the formation of beliefs and the introduction of new meanings.

\section{PRE-LANGUAGE STAGE OF LANGUAGE LEARNING}

Psycholinguistic research provides arguments for the existence of a pre-linguistic fragmentation of the world of experience. The pre-language background is the perceptual, performative and cognitive knowledge of a situation. It precedes and, at the same time, makes it possible to introduce and establish distinctions of a purely linguistic nature 4 .

4 The results of these studies and research can be found in: E. Holenstein, Von der Hintergehbarkeit der Sprache. Kognitive Unterlagen der Sprache. Anhang: Zwei Vorträge von Roman Jakobson, Frankfurt 1980; Badania nad rozwojem języka dziecka, eds. G. Shugar, M. Smoczyńska, Warszawa 1980; J. Piaget, Psychologia i epistemologia, transl. Z. Zakrzewska, Warszawa 1977; Akwizycja języka w świetle językoznawstwa kognitywnego, eds. E. Dą̧browska, W. Kubiński, Kraków 2003. 
Jean Piaget, for example, noticed that with the knowledge of perception, the perception of a sensory characteristic, is usually associated with a functional moment. A child, for example, recognises that a ball is something that can roll, and so it is something with some kind of role in relation to the child's movements. The ball is distinctive in the field of vision because it can be rolled. The child repeats the action of rolling immediately and many times when the ball is in its field of vision - rolling activates and satisfies its ability to move. At the same time, the child perceives the perceptual characteristics of the ball as a more or less round object. Seeing a round ball satisfies the sense of sight, and its subsequent recognition can be explained as identification of the object of the activity with its performance.

The arguments for embedding language in perception and cognitive structures are also provided by the analysis of the early stage of language acquisition - moving from gestures to words. In this stage of development, the child combines linguistic expressions and certain formulation of ideas with specific experiences. It has been observed that in children the connection of motor and linguistic meaning, gesture and word, is preceded by the connection of hand indication with the direction of gaze, thus with two signs already acquired ${ }^{5}$. The progress from gaze and gesture of pointing to verbal indicating (Deixis) is accompanied by a change in the structure of the area of perception, and the progress from objects in the immediate vicinity catching the eye, through increasingly more distant ones, to objects outside the field of vision. It concerns moving from the present things to the absent ones, from signs for the present things to signs for the absent ones ${ }^{6}$.

The property of the described situation is that the object is considered as certain this and certain that, i.e. as an individual object of some kind. This "dual" character of the perceived objects is the basis for the semiotic distinction of the token and type. An object is not

5 E. Clark, From Gesture to Word. Human Growth and Development, Wolson College Lectures, Oxford 1976, 94, 85-120.

6 According to Elmar Holenstein, showing what is absent becomes possible by moving from signs indicating or showing things to signs representing things. E. Holenstein, Von der Hintergehbarkeit der Sprache, op. cit., 25. 
only a ball but also a certain primitive type of sign: a (representative) example of BALLS. To be a ball, an object needs to be round, flexible, and rollable. The aforementioned properties (roundness, flexibility, rollability) allow to identify the given object as a ball.

In the pre-language stage of language acquisition, we find the basis for concepts derived from perception. The process of perception is abstract, it ignores insignificant properties of the object and introduces the perspective of the subject. That is to say, which properties will be chosen and how something is included - as an aspect, a clue or a token - depends on the structure of the perceiving subject. For example, I can see a house from the roof side, or as a token of a house existence when I see only the roof; the same form (shape) that makes an object a knife is also a token that the object can be used as a knife. The sign is based on a specific form usually lines, bars, arrows, longitudinal objects that attract attention. They also point to similar and contrasting things: a white dress can resemble a snowy summit, the person who wore it, but also a black dress. The change of the subjective attitude allows moving from associative to semiotic referencing (Verweisung). We associate the objects thus distinguished with tokens, meanings and see them as token of objects we experience and other tokens. Holenstein convincingly demonstrates how language competence as a distinguishing ability is embedded in the perceptual and motor competence, and how the ability to use symbolic signs (Symbolische Zeichenvermögen) is embedded in the pre-linguistic ability to indicate things (Indexikalischen Zeichenvermögen $)^{7}$. The ability to use symbolic signs such as demonstrative pronouns: This - That - presupposes the understanding of pointing gestures, usually made by the hand (arm) and finger, most often accompanied by direction of the gaze. The experience that something in the field of vision is distinctive and attracts one's own attention and that of one's companion, and is usually accompanied by turning the body in that direction. This behaviour, becoming a token of what is distinctive in the field of vision, thus gains a demonstrative 
function. It appears that we are genetically wired to harness signs indicating. Already in the fifth minute of life, the child is looking for eye contact with the mother, and the seven-week olds are looking adults in the eye rather than in the face to know where their attention is supposed to $\mathrm{go}^{8}$. Understanding linguistic distinctions (phonemes) also presupposes first of all the perception of linguistic signs, i.e. the ability to distinguish sensory signs that function as linguistics signs. The thesis that perceptual concepts are the result of procedures of generalisation and classification of objects, learnt perceptually and functionally, is confirmed by the research on the initial stage of language acquisition, i.e. the stage of encoding concepts ${ }^{9}$. It assumes distinguishing both linguistic expressions (perceiving linguistic signs and awareness of their specificity) and the context of their use. The sign is based on a specific form usually lines, bars, arrows, longitudinal objects that attract attention. Linguistic signs are seen as signs of something and as signs of other signs. Both are interpreted in the same conceptual system. What is coded by a word refers to a specific structure of concepts, related in turn to other such structures. From the point of view of generating or constructing concepts, we can talk about their hierarchy. The same linguistic sign can be used to encode different concepts and, through other concepts, be associated with the whole conceptual system. In this way, the conceptual system participates in the interpretation of the sign, in other words, it expresses its meaning. The conceptual system also stores and interprets, through its structures, the linguistic and situational context of the use of an expression and provides access to any area of the system containing relevant information for interpretation.

8 E. Oksaar, Spracherwerb und Kindersprache in evolutiver Sicht; in Der Mensch und seine Sprache, eds. A. Peisl, A. Mohler, Frankfurt 1979, 149.

9 R. I. Pavilionis, Język, znaczenie, rozumienie i relatywizm, in: Język, znaczenie, rozumienie i relatywizm, Warszawa 1991, 131-169, 135. In the next part, I will refer to Pavilionis' article a number of times. 


\section{THE DESCRIPTIVE CONTENT OF PROPER NAMES AND OCCASIONAL EXPRESSIONS}

How does the conceptual system interpret the meaning of an occasional expression such as me, you, him, here? It has two aspects: (1) conventional (a concept or meaning of the first person speaking); (2) pragmatic (concepts we have about a specific or possible object, the object of reference of the expression). Such an object can be the reference object for many other expressions that are related to a specific information, i.e. concepts that someone has about the given object.

The fact that a name is given is the reason for talking about a "socalled object" in discourse, directing attention at or thinking about it. Similarly, occasional expressions: "I", "you”, "he", "here", "now”, can be considered as the names of the first, second, third person, etc., respectively. They have "fixed" meanings of corresponding expressions. The proper use of occasional expressions presupposes seeing the context of the reference, distinguishing the relevant objects, and constructing a specific concept of a given object in a conceptual system. Therefore, in addition to its conceptual meaning, Pavilionis speaks of a descriptive meaning of proper names or an occasional expression. It is an "image" in some conceptual system that can be established verbally by various descriptors: the object reference then becomes the result of a combination of "established" and "descriptive" meanings ${ }^{10}$. Descriptive meanings are the means of expression and thus the means of representation and presentation of the corresponding objects.

There is no need for the language user to be able to express a "descriptive" meaning. An occasional expression, e.g. "I", cannot be reduced to any descriptor representing my idea of myself. Its inexpressibility is the property of the conceptual system and no verbal expression will exhaust the content associated with it. The "descriptive" meaning as an "image" changes depending on the object itself and our perspective on it. The name retains this object at its every change (e.g. in the fictional 
world), is an inflexible designator, relativized to the conceptual system. It is therefore not it in the sense of objective identity.

When a child knows the structure of a declarative sentence, its utterance is freed from the situation in which the act of speech took place, from the characteristics that once determined the reference the relationship between objects and events and the ways of presenting them is severed. In this situation, a tool is needed that can link the situation to the event expressed in the sentence and the objects included in it. It concerns the identity of time, space and sometimes also people: fulfilling the act of speech and taking part in the described event. This tool are relation-referring demonstratives shifters. They restore the reference to the current situation in a sentence. Shifters demonstrate by means of relation expressions. Reversible relation expressions free us, among other things, from the egocentricity of early childhood perspective. The reference to the situation of the declarative sentence by means of demonstratives (shifters) is chosen at will. As long as the interchangeability of such linguistic indicators ( $I$-you, here-there, left-right) is not established, and shown by being properly used in a dialogue, there is no fixed criterion that they have been used to describe a relation and not as qualifying expressions (thus far). When used as a qualifying expression, they are more related to the specific attitude, as relation descriptors, they testify to the choice of possible positions, possible actions, i.e. a category-related attitude.

Schifters can be compared with relation names, e.g. brother, neighbour, etc.; their use at an early stage of language acquisition is often neither relational nor reflexive but qualifying: "Brother equals a boy"11. Likewise, the use of the pronoun $I$ does not mean gaining self-awareness, certainty of one's own existence, but the discovery of one's own relativity, the interchangeability of roles in social communication overcoming the childish egocentrism. In this context, Jakobson indicated two freeing stages of the child's linguistic development ${ }^{12}$. By

11 D. Elkind, Children's Conceptions of Brother and Sister: Piaget Replication Study V, The Journal of Genetic Psychology 100(1962), 129-136.

12 E. Holenstein, Von der Hintergehbarkeit, op. cit., 186. 
grasping the interchangeability and reflexivity of linguistic indicators, the child is capable of a proper dialogue - the interchangeability of specific linguistic social roles. A partner in a real conversation is not only the sender and recipient of signals but also of symbolic information and confirmations. There is a known example of a child who, before mastering the predictive use of language, could neither initiate a dialogue nor answer purely informative questions with a Yes or $\mathrm{No}^{13}$.

In this context, we can see the reason why proper names and occasional expressions are ideal means of communication. It is so, because they are neutral towards the various concepts associated with them, so there is no need to agree on the associated descriptive terms. Moreover, they allow not only to link different concepts to the same object by one and the same user, but to link different cognitive experiences, to link different thoughts of different language users as presumably referring to the same objects. Therefore, names have a "causal" role: they "evoke", "activate" specific concepts in specific conceptual systems, link together those that presumably choose the same objects in the corresponding object universe, thus enabling communication. Pavilionis stated: "The moral of this is simple: linguistic expressions, and especially proper names and occasional expressions, cannot be considered as directly object-referenced expressions"14. For we always deal with an interpretation in a certain conceptual system.

The acquisition of language means not only mastering the means of coding concepts of a conceptual system, but also mastering the means of social communication, and conventional orientation of such systems. In other words, language not only serves to verbalise the pre-linguistic and linguistic "image" of the world but also to bring individual "images" closer to the "images" of a given language community. It is a medium leading to the establishment of intersubjective distinctions, articulating the world by means of a common code. Learning the correct use of linguistic expressions means acquiring appropriate distinctions, classifications concerning the

13 Ibid, 35.

14 R. I. Pavilionis, Język, znaczenie, rozumienie i relatywizm, op. cit., 138. 
common world in which communicating subjects live. This is the second, besides the coding of concepts, necessary condition for the social communication of individual language users. By manipulating concepts, we can build new conceptual structures, create new "images" of the world, but this logical possibility of creating new concepts is determined by the conceptual system itself. Although they may be far from "images" reflecting the real world, they do not break continuity with concepts reflecting the real experience of the individual. Conceptual structures created by means of language refer to the possible experience of an individual, to possible states of things, unreal, imagined objects - to possible worlds. Once a child is able to build declarative sentences on the basis of what is real, the child can talk about both possible and unreal things.

Thus, mastering a language gives access to "possible worlds". All possible real and unreal, concrete or abstract "images" as conceptual structures are part of a single conceptual system in which they are linked in a continuous manner: "The possibility of crossing the borders of real experience includes the cognitive meaning of symbolism as well as language in general" ${ }^{15}$. Continuity, on the other hand, explains the presence of traces of everyday language in abstract languages.

\section{SENSE AS INTERPRETATION BY MEANS OF A CONCEPTUAL SYSTEM}

The transfer of information from one user to another consists of encoding concepts belonging to a particular conceptual system in some text and then decoding the same text in another system. This process of interpretation is the understanding of a linguistic text as a set of signs.

An expression makes sense if we can find its interpretation in a particular system, covering all possible types of interpretations. The meaning content of a word changes with its verbal environment, not unlike the content (qualitative endowment) of an object depending on the situational context. The means of distinction are hierarchically ordered according to structural relationships of suitability 
and cognateness. Sense is the constructability of a specific "image" by means of the meanings contained in the system. The source of meaning and understanding is linking concepts into a certain unity, to give form, to fill gaps between concepts, to cross differences, distances, contrasts, any kind of incomparability.

This is convincingly demonstrated by the notions of connection, approximation and achievement contained in the etymologies of linguistic expressions that make up the semantic field of the words "to mean" and "to understand". Latin comprehendrere, English to catch, to size, to follow, French saisir, comprendre, German fassen, ergreifen, begreifen, Polish pojmować, ujmować, chwytać, etc. The distance between the subject and the object of understanding can be found in the German verstehen, English understanding. Lithuanian presme (meaning) and suprasti (understand) is the expanding, approximation, acquisition of an object by the subject. Pavilionis, while discussing these examples, believed that in the semantic field of these expressions, the idea of directness, intentionality of the very touchstone of meaning is visible ${ }^{16}$. Let us add that this also concerns the perceptual and functional context (Piaget) of these concepts, which we were discussed earlier.

An example of this is the issue of categorisation in language. The disarticulation of the world is largely done pre-linguistically. There are similarities and differences between individual phenomena, affinities, and internal preferences that guarantee the existence of perceptible distinctions. We therefore rely on them not because they are confirmed by appropriate language expressions but because they are captured by differentiated behaviour. Linguistic distinctions make it possible to correct and clarify distinctions already obtained in perception and action. The fact that we can rely on them is a result of common control and common use of language. Only in this context should we talk about language standardisation. Referring to the research into the function of guidance, introduction, selection and justification by linguistic differentiation of the scope and extent of behaviour, Kuno 
Lorenz argued that we are learning certain behaviours and through these differentiation without being linguistically aware of them ${ }^{17}$.

Sense is therefore a question of interpretation in a specific conceptual system. An expression may be nonsensical in a different system or in a different structure of the same system. The same expression can be interpreted in light of different concepts, which are related to each other in different ways. A system, on the other hand, gives an interpretation when there is an appropriate context that defines the part of the system necessary for interpretation. The context that defines such a fragment of the system are concepts or structures of concepts that are linked due to the relationship of interpretation to concepts directly associated with an object, situation, text, etc. Such a fragment is a block (module) of essential information covering constitutive concepts with different degrees of abstraction and content. The conceptual system, determining what and how we can interpret, also determines our personal view of the world. Its user can not only create meaningful images, but above all, choose those he/she considers true, those he/she accepts - thus not only those which have sense (thus are possible) but also meaningful to him/her. The set of beliefs so distinguished, the individual system of beliefs, is expressed by the so-called propositional attitudes: "I am convinced that...", "I think that...", etc. The individual system of knowledge includes information about everyday experience (including the pre-verbal period of constructing a conceptual system), personal history and systematic knowledge, coded in scientific texts. This objective knowledge includes conventional concepts - an agreed knowledge of the world, the basis for communication between carriers of different conceptual systems. Conventional elements, reflecting the social, cognitive experience of an individual, are intersubjective senses and logical judgments. When considered in isolation from the individual conceptual system, they are transformed into the so-called objective knowledge. Objective knowledge is therefore an abstraction of individual systems of knowledge. On the other hand, it exists

17 K. Lorenz, Elemente der Sprachkritik, Frankfurt 1970, 174. 
symbolically in the body of scientific texts, constituting historically and socially determined "scientific images of the world"18.

\section{EXAMPLES OF THE ROLE OF CONTEXT IN INTERPRETATION OF SEMANTIC ANOMALIES}

The linguistic meaning defined in the concepts of a conceptual system is not a "finished product". It is not always possible to understand a sign by grasping what it means, what it denotes, using only the rules set out by the code. The fact that it is not the sequence of signs constituting the utterance itself that determines its comprehensibility and sense is confirmed by the analysis of the so-called semantic anomalies - a prohibited combination of meanings. For example, the words "to sleep" and "chops", "paint" and "mute" must not be combined - one cannot say chops are sleeping, or the paint is mute, because that would result in a nonsensical statement. Chomsky's famous sentence: "Colourless green ideas sleep furiously" is an example of such a prohibited combination. The collocational restriction is part of the word sense and also determines its use. But is it absolute? Is it not necessary to take into account the context, i.e. the place of a defective sentence in the whole utterance?

Hans Hormann told the following stories:

"Yesterday, behind a freshly painted wall, the police discovered the body of a strangled woman. So far, the police have not managed to find any fingerprints or other clues to help establish the identity of the victim or the murderer - the paint is mute".

"Once, when Chomsky was sixteen and still a secondary-school student, his mother entered his room late at night. Chomsky was already asleep, but he turned anxiously from side to side, gnashing his teeth. Seeing this, Mrs Chomska said: 'Oh! The colourless green ideas sleep furiously'"19.

18 R. I. Pavilionis, Język, znaczenie, rozumienie i relatywizm, op. cit., 146.

19 H. Hörmann, Z zagadnienia procesu rozumienia, in: Prawda i znaczenie. Rozprawy semiotyczne, ed. J. Pelc, Warszawa 1994, 94. 
An incomprehensible sentence starts making sense, after being placed in context - the sense does not automatically result from the systematic translation of characters according to the rules of the code, it was the decision of the listener to interpret this sentence not as incorrect, but as a metaphor. Understanding the sense of expressions is not only the result of grasping what a sign means, but above all of grasping the intentions of the speaker of what he/she means. The listener, attempting to understand what the speaker has in mind, is guided by the principle that the utterance makes sense. That is why he/she analyses signs and word combinations in order to achieve the goal of the above - grasp the sense of the utterance. He/she changes the codes as needed, omits what he/she heard, sometimes ignores the rules of grammar, invents new senses of the word. There is no fixed process, different processes are selected - sense - or lack thereof - is not the property of the sequence of signs or of the utterance itself. It is more accurately described as what the listener achieves.

The concept of sense of linguistic expressions will also remain ambiguous for these reasons. This statement does not discredit its validity. In its light, Quine's scepticism that since it is impossible to define meaning in behavioural concepts, it does not make sense at all to attempt to establish semantics, in the light of selected concepts does not appear appropriate. It is not necessary to justify semantics in this way. Meaning can be discussed in relation to the cognitive and communicative goals set by the speaker and listener, as emphasised by Strawson, Grice, Austin, and Searle, for example. The theory of linguistic meaning should take into account what the user does with it, that is, what he/she could, should, etc., have in mind, using a given expression in a given situation.

The listener is directed towards sense - in the traditional philosophical meaning of the term "to be directed towards [something]", corresponding to the Latin term intendere - because making the world understandable, and hence making utterances in this world understandable, is one of the most important anthropological needs of man, even something necessary for him ${ }^{20}$. The listener, deciding whether he/ 
she is dealing with a semantic anomaly or a metaphor, idiomatic expression or not, actively brings out the sense of the utterance. To this end, he/she must have unclear knowledge of what the speaker may mean in this situation, in this context. Understanding is the concretisation of this knowledge: "In our minds we have, as if, some knowledge of the situation and the actions that people in this situation could take if they decided to act at all. We expect them to act in an understandable way, following to a large extent the same rules, motives, conventions and grammar that we ourselves follow in this situation"21.

This would mean the existence of different levels of understanding, which are determined by the attitude, the interests of the listener. The speaker's utterances refer to something the listener already knows, the latter links the new components to the earlier ones, temporary preconceptions are rejected until the listener considers that he/she has reached the final level of understanding at that moment. In order to achieve the goal - a certain sense, what the speaker has in mind - the listener modifies the existing perception and conceptual patterns. Understanding is not, as we can see, passing on ready-made information, the utterance is rather an instruction for the listener: think this way, perceive these and those relationships. "In this process of creating information, the listener is guided by what he knows about the world, by what the speaker means and says, and by his dominant tendency to perceive events in the world as having sense.... When understanding from the superficial levels penetrates into the deeper, sounds, words and utterances become as if transparent, and in the listener's consciousness appears what the speaker has in mind"22.

\section{CONCLUSIONS}

The above comments lead to the conclusion that the meaning of the expression refers to a broader dynamic model of a conceptual system whose contents are not made of atoms of meaning. The 
meaning cannot be autonomous, it must be considered in relation to the conceptual system, and by extension also to the world. From this point of view, the concepts of referential meanings proposed by Davidson, Kripke, Montaque, and Hintikka, for instance, are closer to explaining the concept of meaning. On the other hand, non-referential concepts, for instance Husserl's presented in Logische Untersuchungen (The Logical Investigations), where the meaning is defined as existing independently of the acts, as something outside the world, identical and unchangeable, should rather be rejected ${ }^{23}$. Likewise, the positions of Frege, Russell and early Wittgenstein, where thoughts are communicable, common to all, objective and exist independently of our grasp and expression ${ }^{24}$. Another example is Chomsky's theory, in which the meaning of utterances is a certain combination of language-independent, innate semantic atoms. Knowing them and the semantic resultant relationships based on them would be the knowledge that the ideal language user has about language as a system (a collection of meanings and semantic relationships). There is no need to refer to the knowledge of the world. There is only one semantics as a competence theory for all language users.

In the light of the above, we should not discuss a system of readymade concepts, ideas, semantic components, etc., but the structure of procedures, operations, achieving results - determining the meaning, determining the sense of utterances, etc. A natural language, in the light of the above considerations, serves to build and symbolically represent the content of the multiplicity of conceptual systems as systems of belief and knowledge. These include different ideas - everyday, scientific and other - about the real and possible world. Language is the means to build these systems. Therefore, language users may have different conceptual ideas about the world. Since linguistic expressions are interpreted within conceptual systems, linguistic meanings should not be detached from these systems and

23 E. Husserl, Badania logiczne, transl. J. Sidorek, Warszawa 2000, 119-124.

24 See: G. Frege, Pisma semantyczne, transl. B. Wolniewicz, Warszawa 1977, 108. 
should be absolutized. When we do this, then language appears as opposed to reality, detached from the processes of acquiring it. The meaning of a sign should be related to its interpretation. The use of signs that require understanding involves the recognition of reality as getting closer to the truth ${ }^{25}$. Pelc, using Twardowski's distinction between acts, activities, actions and processes and their products, claimed that in his description of the activities of transmitting, receiving and processing signs (semiosis), the subject of these activities should be taken into account, similarly, in the analysis of cognition and not of the product - the state of knowledge as all sentences considered true, as well as in the activities of interpretation. "There are no signs outside their use, there is no use of the sign without interpreting it, there is no interpretation of the sign without the cognising subject" 26 . The starting point provided by conceptual systems allows us to question the absolutisation of meaning which is common in natural language philosophy. The theories of Frege, Husserl, Russell, early Wittgenstein, and Chomsky, abstracted from the functions that language performs in cognition and understanding, close the subject within language, which does not allow to explain the references of linguistic expressions, their relation to the objects of the world they signify. From the point of view of the conceptual model of the world, one can think that the reference concepts (Davidson, Kripke, Montaque, and Hintikka) are closer to explaining the issue of meaning.

\section{BIBLIOGRAPHY}

Akwizycja jezyka w świetle językoznawstwa kognitywnego, eds. E. Dąbrowska, W. Kubiński, Kraków 2003.

Badania nad rozwojem jezyka dziecka, eds. G. Shugar, M. Smoczyńska, Warszawa 1980.

25 J. Pelc, Znaczenie i prawda: semioza - poznanie - interpretacja, in: Idem, Znaczenie i prawda. Rozprawy semiotyczne, Warszawa 1994, 13-26.

26 Ibid, 15. 
Clark E., From Gesture to Word. Human Growth and Development, Wolson College Lectures, Oxford 1976.

Elkind D., Children's Conceptions of Brother and Sister: Piaget Replication Study V, The Journal of Genetic Psychology 100(1962), 129-136.

Ey H., La conscience, Paris 1956, $1968^{2}$.

Frege G., Pisma semantyczne, transl. B. Wolniewicz, Warszawa 1977.

Holenstein E., Von der Hintergehbarkeit der Sprache. Kognitive Unterlagen der Sprache. Anhang: Zwei Vorträge von Roman Jakobson, Frankfurt 1980.

Hörmann H., Z zagadnienia procesu rozumienia, in: Prawda i znaczenie. Rozprawy semiotyczne, ed. J. Pelc, Warszawa 1994, 93-102.

Husserl E., Badania logiczne, transl. J. Sidorek, Warszawa 2000.

Lorenz K., Elemente der Sprachkritik, Frankfurt 1970.

Maciejczak M., Brentano i Husserl. Pytanie epistemologiczne, Warszawa 2001.

Oksaar E., Spracherwerb und Kindersprache in evolutiver Sicht; in Der Mensch und seine Sprache, eds. A. Peisl, A. Mohler, Frankfurt 1979, 145-166.

Pavilionis R. I., Jezzyk, znaczenie, rozumienie i relatywizm, in: Jezyk, znaczenie, rozumienie i relatywizm, Warszawa 1991, 131-169.

Pelc J., Znaczenie i prawda: semioza - poznanie - interpretacja, in: Idem, Znaczenie i prawda. Rozprawy semiotyczne, Warszawa1994, 13-26.

Piaget J., Psychologia i epistemologia, transl. Z. Zakrzewska, Warszawa 1977.

Półtawski A., Problematyka doświadczenia „zewnętrznego" w fllozofi Romana Ingardena, Częśc II, Kwartalnik Filozoficzny 24(1996)4, 97-123.

\footnotetext{
Marek Maciejczak

Warsaw University of Technology, Poland

ORCID: https://orcid.org/0000-0001-5199-6651

m.maciejczak@ans.pw.edu.pl
}

DOI: $10.21697 /$ spch.2020.56.S1.09 